\title{
Pemanfaatan Jamban Umum dan Buang Air Besar Sembarangan di Kelurahan Kaliawi Kecamatan Tanjung Karang Pusat Kota Bandar Lampung
}

\section{Utilization of Public Toilets and Open Defecation in Kaliawi Village, Tanjung Karang Pusat District, Bandar Lampung City}

\author{
Evie Karmila, ${ }^{1}$ Fitri Ekasari², Vera Yulyani2* \\ ${ }^{1}$ Dinas Kesehatan Kota Bandar Lampung, Lampung, Indonesia \\ ${ }^{2}$ Fakultas Kesehatan Masyarakat, Universitas Malahayati, Lampung, Indonesia \\ *Korespondensi penulis: verayulyani@malahayati.ac.id
}

Penyerahan: 26-08-2020, Perbaikan: 08-09-2020, Diterima: 22-09-2020

\begin{abstract}
The city of Bandar Lampung to date has 9,341 families who defecate. Kelurahan Kaliawi is the biggest contributor in Tanjung Karang Pusat Subdistrict, which has a large number of residents who practice defecation and do not have latrines. The research aimed to dig deeper information about the use of public latrines and defecation behavior for the people of Kaliawi area. Qualitative research with a case study design. The subjects in this study consisted of key informants, namely the head of the village, health officers of the sanitarian program and health cadres, companion informants, namely people who did not defecate, and the main informants, namely people who practiced BABS. data obtained through indepth interviews and observations of defecation sites. Data analysis using content analysis with interview matrix. The results of the interview showed that most of the informants did not have latrines and practiced defecation, most informants had a poor perception, a small proportion of informants expressed a positive attitude, all informants stated that they did not care about other people's views on BABS behavior, some informants stated that they knew Defecation behavior is not good, most informants do not have the cost and a difficult place to permit the construction, the existence of public toilets is far from the reach of the community. It is hoped that the local government will build public toilets in a strategic location so that they can be reached by the community and make laws and regulations not to practice defecation and to maintain the cleanliness of public latrines together.
\end{abstract}

Keywords: Open Defecation, Latrine Utilization.

\begin{abstract}
ABSTRAK
Kota Bandar Lampung memiliki jumlah masyarakat yang BABS sebanyak 9.341 KK. Kelurahan Kaliawi merupakan penyumbang terbesar di Kecamatan Tanjung Karang Pusat yang jumlah penduduknya banyak melakukan BABS dengan menggunakan kantong plastik. Tujuan penelitian ini adalah untuk menggali informasi lebih dalam mengenai pemanfaatan jamban umum dan perilaku BABS bagi masyarakat daerah Kaliawi. Penelitian kualitatif dengan rancangan studi fenomena. subyek dalam penelitian ini terdiri dari informan kunci yaitu lurah, petugas kesehatan program sanitarian dan kader kesehatan, informan pendamping yaitu masyarakat yang tidak melakukan BABS, dan informan utama yaitu masyarakat yang melakukan BABS. data diperoleh melalui wawancara mendalam dan observasi tempat buang air besar. analisa data menggunakan content analysis dengan matriks wawancara. Hasil wawancara terdapat sebagian besar informan tidak memiliki
\end{abstract}

Jurnal Dunia Kesmas, Vol. 10 No. 3, Juli 2020, hal. 521-528

521

ISSN 2301-6604 (Print), ISSN 2549-3485 (Online)

http://ejurnalmalahayati.ac.id/index.php/duniakesmas/index 
jamban dan melakukan BABS, sebagian besar informan memiliki persepsi yang kurang baik, sebagian kecil informan menyatakan sikap yang positif, semua informan menyebutkan bahwa tidak peduli dengan pandangan orang lain terhadap perilaku BABS, sebagian informan menyatakan bahwa mereka tahu perilaku BABS tidak baik, sebagian besar informan tidak memiliki biaya dan tempat perizinan pembangunan yang sulit, sedangkan keberadaan jamban umum berada jauh dari jangkauan masyarakat. Diharapkan kepada pemerintah setempat untuk membangun jamban umum di lokasi yang strategis agar dapat dijangkau oleh masyarakat dan membuat aturan perundangundangan untuk tidak melakukan BABS dan menjaga kebersihan jamban umum secara bersama.

Kata kunci: Buang Air Besar Sembarangan, Pemanfaatan Jamban.

\section{PENDAHULUAN}

Sanitasi adalah perilaku disengaja dalam pembudayaan hidup bersih (Prüss-Üstün et al., 2008). Kemajuan akses sanitasi yang lambat dapat mengancam dan merusak kelangsungan hidup masyarakat (WHO/UNICEF, 2015). Sanitasi terutama di perkotaan merupakan masalah yang rumit, kompleks baik secara teknis, sosial dan manajemen (Colin et al., 2009).

Pada tahun 2017, diperkirakan 673 juta orang masih buang air besar di tempat terbuka, bukan di jamban yang dikenal sebagai Buang Air Besar Terbuka (BABS) yang menunjukkan perilaku sanitasi yang buruk (Grojec, 2015; Steele, 2019). Buang air besar di tempat terbuka memiliki dampak yang parah pada anak-anak kesehatan dan berkontribusi pada sejumlah besar kematian dini (Mara, 2017; Yalew, 2014).

Di era modern ini, masih banyak orang yang mempraktekkan Buang Air Besar Sembarangan (BABS). Perkembangan teknologi, dan pertukaran informasi yang mudah bukanlah jaminan dalam mengubah perilaku masyarakat, bahkan di daerah perkotaan yang dengan cepat memiliki akses internet. ("World Health Statistics 2016 - Monitoring Health For The SDGs," 2016).
Penelitian tentang penyebab BABS telah banyak dilakukan, namun sebagian besar fokus penelitian dilakukan di wilayah perdesaan, sementara daerah perkotaan belum banyak diteliti (O'Connell, 2014; Yulyani et al., 2019). Penelitian di daerah perkotaan jarang dilakukan terutama daerah kumuh kota sering kali diabaikan (Augsburg et al., 2016).

Indonesia adalah negara dengan jumlah populasi yang tinggi (lebih dari 58 juta) di Indonesia masih mempraktekkan buang air besar di daerah perkotaan (37\%) dan daerah pedesaan (43\%) (Annual Report Indonesia 2015, 2016). Bersama dengan Lembaga Dunia Kesehatan (WHO) Kementerian Kesehatan Indonesia telah mengeluarkan peraturan yang dikenal sebagai Sanitasi Total Berbasis Masyarakat (STBM) sejak 2008 untuk menurunkan jumlah masyarakat yang melakukan BABS. Setelah 1 tahun pasca pemicuan STBM, setiap kelurahan diwajibkan melakukan deklarasi kelurahan ODF (Pedoman Pelaksanaan Sanitasi Total Berbasis Masyarakat Dalam Program Kesehatan Dan Gizi Berbasis Masyarakat (PKGBM), 2015).

Sanitasi Total Berbasis Masyarakat (STBM) adalah pendekatan untuk 
mengubah perilaku higienis dan saniter melalui pemberdayaan masyarakat dengan cara pemicuan. Capaian ODF di Kota Bandar Lampung terbilang lebih lambat dibandingkan dengan Kota Metro, Pringsewu dan Way Kanan yang telah deklrasi sebagai kabupaten ODF (Laporan Kemajuan ODF, 2019).

Kota Bandar Lampung memiliki 126 kelurahan dengan jumlah kelurahan yang belum melakukan STBM sebanyak 34 kelurahan dan 90 diantaranya belum Open Defecation Free (ODF) (Laporan Kemajuan Akses Sanitasi, 2019). Sulitnya capaian ODF di Kota Bandar Lampung dipengaruhi dari banyak faktor, dari sulitnya akses air bersih dan jamban, hingga banyaknya masyarakat bukan penduduk tetap yang sudah tinggal bertahun-tahun tidak menerapkan perilaku hidup bersih dan sehat.

Provinsi Lampung sebagai daerah yang cukup besar penduduknya memiliki jumlah masyarakat yang melakukan BABS sebanyak 161.787 $\mathrm{KK}$, dan yang jamban sharing sebanyak $107.570 \mathrm{KK}$. Kota Bandar Lampung sendiri sebagai ibu kota Provinsi Lampung memiliki jumlah masyarakat yang BABS sebanyak $9.341 \mathrm{KK}$. dan sekitar $10 \%$ penduduk di Kecamatan Tanjung Karang Pusat yang letaknya tepat di tengah ibu Kota Bandar Lampung juga melakukan BABS (Laporan Kemajuan Akses Sanitasi, 2019).

Kecamatan Tanjung Karang Pusat memiliki 7 kelurahan, dari 7 kelurahan tersebut Kelurahan Kaliawi merupakan penyumbang terbesar di Kecamatan Tanjung Karang Pusat yang jumlah penduduknya banyak melakukan BABS dan belum memiliki jamban yakni sebanyak 180 KK (Puskesmas Palapa, 2019). Beragam faktor menjadi penyebab banyaknya masyarakat melakukan perilaku BABS.
Survey pendahuluan di wilayah penelitian ini menunjukkan bahwa terdapat beberapa jamban umum yang telah dibangun oleh pemerintah setempat dalam rangka menanggulangi fenomena ini, namun jamban umum tersebut tidak terawat dan bahkan banyak yang tidak dapat digunakan kembali. Rendahnya kesadaran masyarakat untuk bertanggung jawab dalam mengelola jamban yang telah dibangun menjadi dasar pemikiran penelitian ini. Belum adanya kesadaran masyarakat untuk saling menjaga dan membersihkan jamban bersama sehingga membuat jamban bersama cepat rusak membuat permasalahan mengenai BABS di daerah ini menjadi sangat kompleks.

Penelitian ini akan mengambil pendekatan kualitatif untuk menggali lebih dalam penyebab masyarakat daerah Kaliawi dalam memanfaatkan jamban umum dan melakukan BABS, serta menggali persepsi resiko, sikap, norma, kemampuan dan regulasi diri, serta titik-titik akses jamban umum dalam mereduksi kebiasaan ini. Banyaknya masyarakat yang melakukan BABS di kota besar akibat tidak memiliki jamban inilah yang menjadi latar belakang peneliti untuk melakukan penelitian dengan tujuan adalah menganalisis akses jamban dan perilaku BABS pada masyarakat Kaliawi.

\section{METODE}

$\begin{array}{ccc}\text { Jenis } & \begin{array}{c}\text { Penelitian ini adalah } \\ \text { pualitatif }\end{array} \\ \text { dengan }\end{array}$ rancangan penelitian yang digunakan adalah studi fenomena. Sumber informasi dari penelitian ini diperoleh dari beberapa informan. Informan utama dalam penelitian adalah masyarakat yang melakukan BABS. Pengambilan informan dalam penelitian kualitatif menggunakan Purposive Sampling, yaitu 
pengambilan

berdasarkan

pertimbangan

pengumpulan asi dan wawancara mendalam serta dokumentasi. Analisis data penelitian dengan reduksi data, penyajian data, verifikasi data hingga penarikan kesimpulan.

\section{HASIL}

Hasil penelitian yang dilakukan melalui wawancara mendalam tentang akses dan perilaku BABS diketahui bahwa sebagian besar responden tidak memiliki jamban.

Seperti pernyataan informan berikut:

".....tidak punya jamban, ada sih jamban umum tapi males jorok" (Tn. E 44 tahun)

"...tidak punya jamban, WC umum ada dibawah tapi kejauhan" (Ny. L 57 tahun)

Selain tidak memiliki jamban, semua informan menyatakan bahwa akses untuk mendapatkan air bersih menggunakan selang dari sumur bor.

"...pakai selang, kalau kita ngomong hari ini 2 hari kemudian baru airnya dapet" (Tn E 44 tahun)

"...pake air sumur bor, nyelang" (Ny M 27 tahun)

Sebagian besar informan lebih memilih untuk menggunakan plastik dan ke gunung dibandingkan ke jamban umum karena air di jamban umum juga sulit sehingga mereka terpaksa membawa air dari rumah.

"....kita juga harus bawa air sendiri kalau mau wc umum, ya ribet mbak mana per 2 jam bayar 7000" (Tn E 44 tahun)
Dari hasil wawancara mendalam didapatkan 4 informan lainnya memiliki persepsi yang kurang baik dengan mangatakan bahwa sudah kebal terhadap penyakit dan jarang sakit meskipun melakukan BABS dengan plastik.

"...ga ngerti sih ya, kayaknya udah kebal yang begituan mah" (Ny S 40 tahun)

"...kurang tau ya, kayaknya sama aja namanya penyakit mah dampaknya kemana-mana" (Ny L 57 tahun)

Seluruh informan menyatakan bahwa nilai pandangan masyarakat jika melakukan buang air besar tidak dijamban merupakan hal yang biasa karena sudah terlalu sering melakukan BABS.

"...biasa saja, ada wc umum tapi jauh banget harus kebawah, terus malu juga kalau harus kebawah" (Ny. M 27 tahun)

"...biasa saja tidak jadi masalah" (Ny $S 40$ tahun)

\section{PEMBAHASAN}

Perilaku buang air besar di tempat terbuka seperti sungai, kebun dan tanah, termasuk penggunaan jamban tanpa septic tank atau perilaku buang air besar yang berpotensi dalam menyebarkan penyakit. Hasil wawancara dengan tokoh setempat menyebutkan bahwa terdapat 3 jamban umum di kelurahan ini,pengelolaan dari masyarakat yang kurang baik sehingga kebersihannya tidak dijaga dan tidak ada rasa ingin memiliki menyebabkan perilaku BABS telah menjadi rahasia umum di Kelurahan Kaliawi. Hasil ini dipertegas dengan observasi lingkungan yang dilakukan peneliti menunjukkan kondisi jamban umum yang tidak layak.Kondisi jamban 
umum di kelurahan ini terlihat kotor, dan tidak berfungsi dengan baik.

Sebagian besar informan yang diwawancarai menjelaskan lebih memilih buang air besar di gunung atau dengan "plastik terbang" atau di selokan dibandingkan untuk menggunakan jamban umum. Hal yang melatarbelakanginya adalah : 1 ) kondisi jamban umum yang kotor, 2) jarak yang terlalu jauh.

Hasil ini sejalan dengan penelitian sebelumnya yang menyebutkan bahwa tingkat penggunaan jamban umum pada masyarakat yang tidak memiliki jamban berkisar antara 15$100 \%$.Faktor-faktor penentu penggunaan fasilitas jamban umum di antara rumah tangga yang tidak memiliki jamban adalah akses dan kenyamanan (jarak dan jam buka), usia fasilitas, biaya pemeliharaan atau kebersihan, dan biaya. Rasio pengguna pria dan wanita adalah $2: 1$ di semua fasilitas untuk orang dewasa dan anak-anak(Biran et al., 2011).

Penyediaan fasilitas jamban umum mampu mengurangi tetapi tidak mengakhiri masalah BABS di kantong-kantong kemiskinan di wilayah perkotaan.Perempuan tampaknya relatif kurang terlayani oleh jamban umum dan, biaya merupakan penghalang untuk dibangunnya jamban pribadi oleh rumah tangga miskin.

Masalah sanitasi di wilayah perkotaan terutama disebabkan oleh : 1) Iahan tanah yang sempit, 2) tidak adanya tempat saluran pembuangan air limbah, 3) jamban umum dengan kualitas yang kurang baik. Masyarakat yang berbagi jamban atau menggunakan jamban umum cenderung untuk melakukan BABS.Fasilitas bersama cenderung tidak berfungsi, kurang bersih, dan lebih cenderung memiliki kotoran dan lalat (Heijnen et al., 2015).
Masalah sanitasi perkotaan sangat rumit secara teknis, sosial dan manajemen.Ketika kota berkembang pesat, seringkali infrastuktur untuk sanitasi di wilayah perkotaan sudah usang dan sebagian besar tidak dirawat dengan baik, hanya sebagian kecil air limbah yang diolah dan dibuang dengan aman. Pengembangan kebijakan di sektor ini berfokus pada layanan air dan sanitasi berbasis masyarakat (STBM) yang secara efektif hanya baik jika dilakukan di wilayah perdesaan, hanya sedikit pengembangan kebijakan khusus di wilayah perkotaan (Colin, 2011).

Menurut pendapat peneliti, masyarakat tidak mau gunakan wC umum karena biasanya wc umum kotor, penempatan wc umum juga terlalu jauh, serta tidak ada air di wc umum sehingga masyarakat harus membawa air sendiri dari atas.

Berdasarkan hasil wawancara 4 dari 6 responden memiliki persepsi yang kurang baik dengan mangatakan bahwa sudah kebal terhadap penyakit dan jarang sakit meskipun melakukan BABS dengan plastik. Didukung dengan pernyataan dari tokoh setempat yang menyatakan bahwa masyarakat banyak yang tidak peduli terhadap kejadian sakit meskipun berulangkali telah dilakukan edukasi. Hasil ini sejalan dengan teori yang telah disampaikan bahwa persepsi resiko yang tidak baik akan mempengaruhi perilaku masyarakat menjadi tidak baik (Contzen \& Mosler, 2015). Masyarakat yang merasa kebal terhadap terjadinya sakit diare atau penyakit lain akan berperilaku BABS. Sejalan dengan penelitian yang menyebutkan bahwa persepsi resiko yang baik memotivasi penerapan perilaku positif yang berhubungan dengan perilaku sanitasi dan perilaku melindungi 
kesehatan, serta sebaliknya (Anthonj et al., 2018).

Persepsi risiko - atau persepsi kerentanan seseorang terhadap suatu ancaman - adalah komponen kunci dari banyak teori perubahan perilaku kesehatan.Persepsi risiko sering ditargetkan dalam intervensi perubahan perilaku kesehatan, dan bukti meta-analitik baru-baru ini menunjukkan bahwa intervensi yang berhasil melibatkan dan mengubah persepsi risiko menghasilkan peningkatan perilaku kesehatan selanjutnya.Secara keseluruhan, penelitian yang ada menunjukkan bahwa persepsi risiko penyakit merupakan penentu penting perilaku kesehatan, meskipun sifat hubungan antara persepsi risiko dan perilaku kesehatan mungkin tergantung pada profil berbagai jenis persepsi risiko dan keakuratan persepsi tersebut (Ferrer \& Klein, 2015).

Persepsi resiko kesehatan kurang baik menurut peneliti karena masyarakat telah tinggal sejak lama di daerah tersebut.Hal ini menyebabkan masyarakat berpikir kebal dan sudah terbiasa dengan terjadinya penyakit diare.

Sebagian kecil informan yang diwawancarai menyatakan sikap yang positif untuk tidak melakukan BABS, dari hasil wawancara tersebut menyatakan sangat penting sekali memiliki jamban pribadi. Namun pernyataan ini bertolak belakang dengan penyataan evaluatif berikutnya dari informan yang menyatakan bahwa biaya pembangunan jamban dirasa cukup mahal dan kesulitan untuk memberikan biaya ganti rugi kepada pemilik tanah.

Sikap merepresentasikan tentang sikap positif atau negatif seseorang. Dimana hal ini berkaitan dengan kepercayaan tentang biaya dan keuntungan serta perasaan masyarakat (Contzen \& Mosler, 2015).Sejalan dengan penelitian yang dilakukan di Ghana yang menyebutkan bahwa sikap hanya berkontribusi sebesar 5,8\% terhadap perilaku. Temuan penelitian ini menyebutkan bahwa sikap yang positif tidak dapat diterjemahkan dalam praktik sanitasi yang sebenarnya. Ada kesenjangan antara sikap responden terhadap perasaan dan keuntungan dari sanitasi dan sikap mereka terhadap standar praktik (Safo-adu, 2019)

Kontradiktif pernyataan dari hasil wawancara antara kepercayaan masyarakat tentang keuntungan dari perilaku BABS dan kesulitan biaya dalam pembangunan jamban pribadi yang diwujudkan dalam perilaku BABS oleh masyarakat itu sendiri menunjukkan bahwa faktor ekonomi menjadi kendala besar untuk membentuk perilaku yang baik dari hasil sikap yang positif.

Hasil wawancara dengan informan utama menyebutkan bahwa tokoh masyarakat dan lingkungan sekitar sering menganjurkan masyarakat untuk BAB tidak dilakukan sembarangan. Bagi informan utama perilaku BABS merupakan hal yang sudah biasa dan merasa hal ini bukanlah masalah. Semua informan menyebutkan bahwa tidak peduli dengan pandangan orang lain terhadap perilaku mereka.

Hasil wawancara dengan tokoh masyarakat menegaskan bahwa telah sering melakukan himbauan pada masyarakat untuk tidak BABS dan telah menyediakan jamban umum, perilaku ini telah menjadi hal yang biasa meskipun merasa miris dan sedih terhadap perilaku BABS tersebut. Tokoh masyarakat selama ini baru melakukan himbauan yang sifatnyatidak memaksa.Lebih lanjut, tokoh masyarakat berharap ada peraturan daerah tentang 
sanitasisehingga dapat lebih diperhatikan oleh masyarakat.

Menurut teori Reasoned Action norma dipengaruhi oleh keyakinan akan pendapat orang lain untuk menaati keyakinan akan pendapat orang lain tersebut. Orang akan melakukan suatu tindakan apabila memiliki nilai positif dari pengalaman yang sudah ada dan tindakan tersebut didukung oleh lingkungan (Montaño \& Kasprzyk, 2008). Seorang individu akan melakukan suatu perilaku tertentu jika perilakunya dapat diterima oleh orang-orang yang dianggapnya penting dalam kehidupannya dapat menerima apa yang akan dilakukannya.

Hasil penelitian ini mendukung teori yang ada dimana masyarakat menganggap bahwa perilaku BABS adalah hal yang sudah biasa dan dilumrahkan oleh masyarakat sekitar dan tokoh masyarakat. Tekanan dari lingkungan sosial tidak terlalu besar untuk memaksa masyarakat tidak melakukan BABS dan membangun jamban pribadi, selain itu tidak ada peraturan derah yang sifatnya memaksa sehingga hal ini menjadi kelonggaran bagi masyarakat.

\section{KESIMPULAN}

Berdasarkan hasil wawancara akses dan perilaku BABS dari 6 responden, sebagian besar responden tidak memiliki jamban dan melakukan buang air besar menggunakan kantong plastik. Persepsi risiko masyarakat didapatkan sebagian besar responden memiliki persepsi yang kurang baik dengan mangatakan bahwa sudah kebal terhadap penyakit dan jarang sakit meskipun melakukan BABS dengan plastik. Berdasarkan hasil wawancara terkait sikap masyarakat didapatkan sebagian kecil responden yang diwawancarai menyatakan sikap yang positif untuk tidak melakukan BABS, namun semua responden menyatakan sudah menjadi hal yang biasa melakukan BABS. Norma masyarakat didapatkan seluruh responden utama menyatakan perilaku BABS merupakan hal yang sudah biasa dan merasa hal ini bukanlah masalah. Semua informan menyebutkan bahwa tidak peduli dengan pandangan orang lain terhadap perilaku mereka. Kemampuan masyarakat didapatkan hasil sebagian besar informan menyatakan percaya akan kemampuannya untuk merawat dan membersihkan jamban bila dibangunkan jamban umum. Pernyataan ini tidak sejalan dengan pernyataan informan kunci yang menyatakan bahwa bila jamban sendiri akan dijaga dengan baik tetapi masyarakat pernah dibangunkan jamban dan tidak mampu merawatnya dengan baik. Berdasarkan hasil wawancara terkait regulasi diri masyarakat didapatkan sebagian besar dari responden sangat menginginkan memiliki jamban pribadi namun tidak memiliki biaya dan tempat perizinan pembangunan yang sulit karena tanah sewa.

\section{SARAN}

Diharapkan bagi pihak Puskesmas untuk meningkatkan upaya pengembangan program STBM kepada masyarakat yang belum memiliki jamban dengan lebih meningkatkan lagi sistem pemicuan. Diharapkan kepada pemerintah setempat untuk membangun jamban umum di lokasi yang strategis agar dapat dijangkau oleh masyarakat dan membuat aturan perundangundangan untuk tidak melakukan BABS dan menjaga kebersihan jamban umum secara bersama. 


\section{DAFTAR PUSTAKA}

Annual Report Indonesia 2015. (2016). UNICEF INDONESIA.

Anthonj, C., Fleming, L., Godfrey, S., Ambelu, A., Bevan, J., Cronk, R., \& Bartram, J. (2018). Health Risk Perceptions Are Associated with Domestic Use of Basic Water and Sanitation Services - Evidence from Rural Ethiopia. International Journal of Environmental Research and Public Health, 15, 1-19. https://doi.org/10.3390/ijerph15 102112

Augsburg, B., Abramovsky, L., Flynn, E., \& Oteiza, F. (2016). Improving CLTS targeting: evidence from Nigeria.

https://doi.org/10.1920/bn.ifs.20 16.0183

Biran, A., Jenkins, M. W., Dabrase, P., \& Bhagwat, I. (2011). Patterns and determinants of communal latrine usage in urban poverty pockets in Bhopal, India. Tropical Medicine and International Health, 16(7), 854-862. https://doi.org/10.1111/j.13653156.2011.02764.x

Colin, J. (2011). Lessons in Urban Sanitation Indonesia Sanitation Sector Development. May.

Colin, J., Keetelaar, C., Utomo, N. T., \& Blackett, I. (2009). Urban Sanitation in Indonesia: Planning for Progress. April, 1-24. https://doi.org/10.13140/RG.2.2. 31191.88483

Contzen, N., \& Mosler, H.-J. (2015). The RANAS approach to systematic behavior change. Methodological Fact Sheet 1. Eawag, October. https://www.eawag.ch/fileadmin/ Domain1/Abteilungen/ess/schwer punkte/ehpsy/RANAS_Methodolo gical_Fact_Sheets.pdf

Ferrer, R. A., \& Klein, W. M. P. (2015). Risk perceptions and health behavior. Current Opinion in Psychology, 5(April), 85-89. https://doi.org/10.1016/j.copsyc. 2015.03.012

Grojec, A. (2015). Progress on Sanitation and Drinking Water (2015 Update and MDG Assessment). UNICEF and World Health Organization. http://www.who.int/water_sanita tion_health/publications/jmp2015-update/en/

Heijnen, M., Routray, P., Torondel, B., \& Clasen, T. (2015). Shared sanitation versus individual household latrines in urban slums: A cross-sectional study in orissa, India. American Journal of Tropical Medicine and Hygiene, 93(2), 263-268.

https://doi.org/10.4269/ajtmh. 14 $-0812$

Laporan Kemajuan Akses Sanitasi. (2019). Kementerian Kesehatan RI.

http://monev.stbm.kemkes.go.id/

Laporan Kemajuan ODF. (2019). Kementerian Kesehatan RI. http://monev.stbm.kemkes.go.id/

Mara, D. (2017). The elimination of open defecation and its adverse health effects: a moral imperative for governments and development professionals. Journal of Water Sanitation and Hygiene for Development, 7(1), 1-12. https://doi.org/10.2166/washdev .2017 .027

Montaño, D., \& Kasprzyk, D. (2008). Theory of reasoned action, theory of planned behaviour, and the integrated behavioral model. In Health Behaviour and Health Education. Theory, Research, and Practice.

https://doi.org/10.1016/S00333506(49)81524-1

O'Connell, K. (2014). What influences open defecation and latrine 
ownership in rural households?: Findings from a global review (Issue August). Water and Sanitation Program. https://www.issuelab.org/resourc es/19200/19200.pdf

Pedoman Pelaksanaan Sanitasi Total Berbasis Masyarakat dalam Program Kesehatan dan Gizi Berbasis Masyarakat (PKGBM) (Issue 21). (2015). http://www.mcaindonesia.go.id/assets/uploads/m edia/pdf/Pedoman-PelaksanaanSTBM.pdf

Prüss-Üstün, A., Bos, R., Gore, F., \& Bartram, J. (2008). Safer water, better health. World Health Organization, 53. https://doi.org/ISBN 9789241596435

Puskesmas Palapa. (2019). Laporan Keadaan Sanitasi Puskesmas Palapa.

Safo-adu, G. (2019). Sanitation Attitudes of Urban Dwellers and their Influence on Sanitation Sanitation Attitudes of Urban Dwellers and their Influence on Sanitation Practices in Central Region of Ghana. International Journal of Toxicology and Environmental Health, 4(2).

Steele, R. (2019). Progress on Household Drinking Water, Sanitation and Hygiene 20002017. WHO/UNICEF Joint Monitoring Programme for Water Supply and Sanitation (JMP). https://www.unicef.org/reports/p rogress-on-drinking-watersanitation-and-hygiene-2019

WHO/UNICEF. (2015). Progress On Sanitation and Drinking Water 2015 Update and MDG Assessment.

World Health Statistics 2016 Monitoring Health For The SDGs. (2016). In World Health
Organization. World Health Organization.

https://doi.org/10.1017/CB09781 107415324.004

Yalew, B. M. (2014). Prevalence and Factors Associated with Stunting, Underweight and Wasting: A Community Based Cross Sectional Study among Children Age 6-59 Months at Lalibela Town, Northern Ethiopia. Journal of Nutritional Disorders \& Therapy, 04(02). https://doi.org/10.4172/21610509.1000147

Yulyani, V., Nuryani, D. D., \& Kurnia, D. (2019). Latrine Use And Associated Factors Among Rural Community In Indonesia. Malaysian Journal of Public Health Medicine, 19(1), 143-151. https://doi.org/http://10.0.20.16 1/zenodo.3375462 